Resumen por el autor, G. J. Noback.

Métodos simples para la correlacicn de las longitudes occipuciorabadilla y occipucio-talón del feto humano.

El autor presenta una fórmula que hace posible la utilización de datos sobre el feto humano en términos de la longitud desde el occipucio a la rabadilla (altura del ejemplar sentado) la cual se desea comparar o combinar con datos semejantes expresados en la longitud desde el occipucio a los talones (altura total o altura del ejemplar en pié). La fórmula mencionada es la siguiente:

$$
\mathrm{CH}-\frac{3 \mathrm{CR}-3}{2}
$$

en la cual $\mathrm{C}$ corresponde a occipucio, $\mathrm{H}$ a talones y $\mathrm{R}$ a rabadilla.

Para determinar la longitud desde el occipucio a la rabadilla cuando se conoce la del occipucio a los talones se puede emplear una segunda formula:

$$
\mathrm{CR}=\frac{2 \mathrm{CH}+3}{2}
$$

Para determinar la exactitud de las fórmulas precedentes se han empleado las observaciones de varios investigadores que han publicado datos basados en ambas longitudes.

Translation by José F. Nonidez Cornell Medical College, New York 
AUTHOR'S ABSTRACT OF THIB PAPER ISSUED

BY THE BIBLIOGRAPHIC BERVICE, MARCH 27

\title{
SIMPLE METHODS OF CORRELATING CROWN-RUMP AND CROWN-HEEL LENGTHS OF THE HUMAN FETUS ${ }^{1}$
}

\author{
G. J. NOBACK
}

University of Minnesota and the Medical College of Virginia

ONE FIGURE

Investigators in prenatal anatomy and development report their findings in one of three ways as regards length of the individuals studied. Some writers use both crown-rump and crownheel length (Michaelis, '06; Mall, '10). Others use only the crown-rump (Streeter, '20), and some use the crown-heel alone (Meyer, '15; Scammon, '19; Noback, '21). Work based on one of these measurements alone is obviously difficult to compare with work based upon the other.

The relation between the crown-rump and the crown-heel lengths during fetal life is practically constant. The formulae here presented further demonstrate this fact.

The crown-heel length of the human fetus is equal to the crown-rump length (in millimeters) minus one, plus one-half of this amount. The following formula makes possible the utilization of data reported in crown-rump length which is to be compared or combined with data based upon the crown-heel length alone.

$$
\mathrm{CH}=\frac{3 \mathrm{CR}-3}{2}
$$

Illustration: The known crown-rump length is $95 \mathrm{~mm}$. What is the corresponding crown-heel length?

$$
\mathrm{CH}=\frac{3 \times 95-3}{2}
$$

i.e., the crown-heel length is $141 \mathrm{~mm}$.

${ }^{1}$ The formulae in this report were demonstrated at the thirty-seventh session of the American Association of Anatomists, March, 1921. 
The second formula may be used to determine the crownrump length when the crown-heel length is known. It is expressed as follows:

$$
\mathrm{CR}=\frac{2 \mathrm{CH}+3}{3}
$$

Illustration: The known crown-heel length is $141 \mathrm{~mm}$. What is the corresponding crown-rump length?

$$
\mathrm{CR}=\frac{2 \times 141+3}{3}
$$

i.e., the crown-rump length is $95 \mathrm{~mm}$.

In order to determine to what extent measurements made by different observers would deviate from the formulae, I have plotted them on ordinate paper against the curve obtained by use of the formulae. The crown-rump lengths are represented by the abscissas and the crown-heel lengths by the ordinates. The accompanying plate shows the formulae curve as a straight line, and it is readily seen that the measurements made by the several observers are distributed quite evenly about it. ${ }^{2}$

The following table shows the extent of deviation from the lengths derived by formula in the data of Mall, MacKeen, and

\begin{tabular}{|c|c|c|}
\hline & $\begin{array}{c}\text { AVERAGE } \\
\text { DEVIATION }\end{array}$ & $\begin{array}{c}\text { PERCENT- } \\
\text { AGH } \\
\text { DEVIATION }\end{array}$ \\
\hline Mall (weekly averages of 1000 cases)... & 2.4 & 0.7 \\
\hline MacKeen $(161$ cases $) \ldots \ldots \ldots \ldots \ldots \ldots \ldots \ldots \ldots$ & 9.5 & 3.6 \\
\hline Michaelis (weekly averages from 14 weeks to birth). & 11.5 & 3.3 \\
\hline
\end{tabular}
Michaelis.

Two sets of data on measurements of the newborn infant are also plotted against the curve. These observations were made by Taylor ' 19 and by Weissenberg '06. The averages of their measurements vary but a trifle from the curve derived by the formulae.

${ }^{2}$ Besides data of Mall and of Michaelis I have used measurements made in the Institute of Anatomy, University of Minnesota, by Helen Adams MacKeen and by Halbert Dunn. The work of the latter two investigators will appear in due course. 


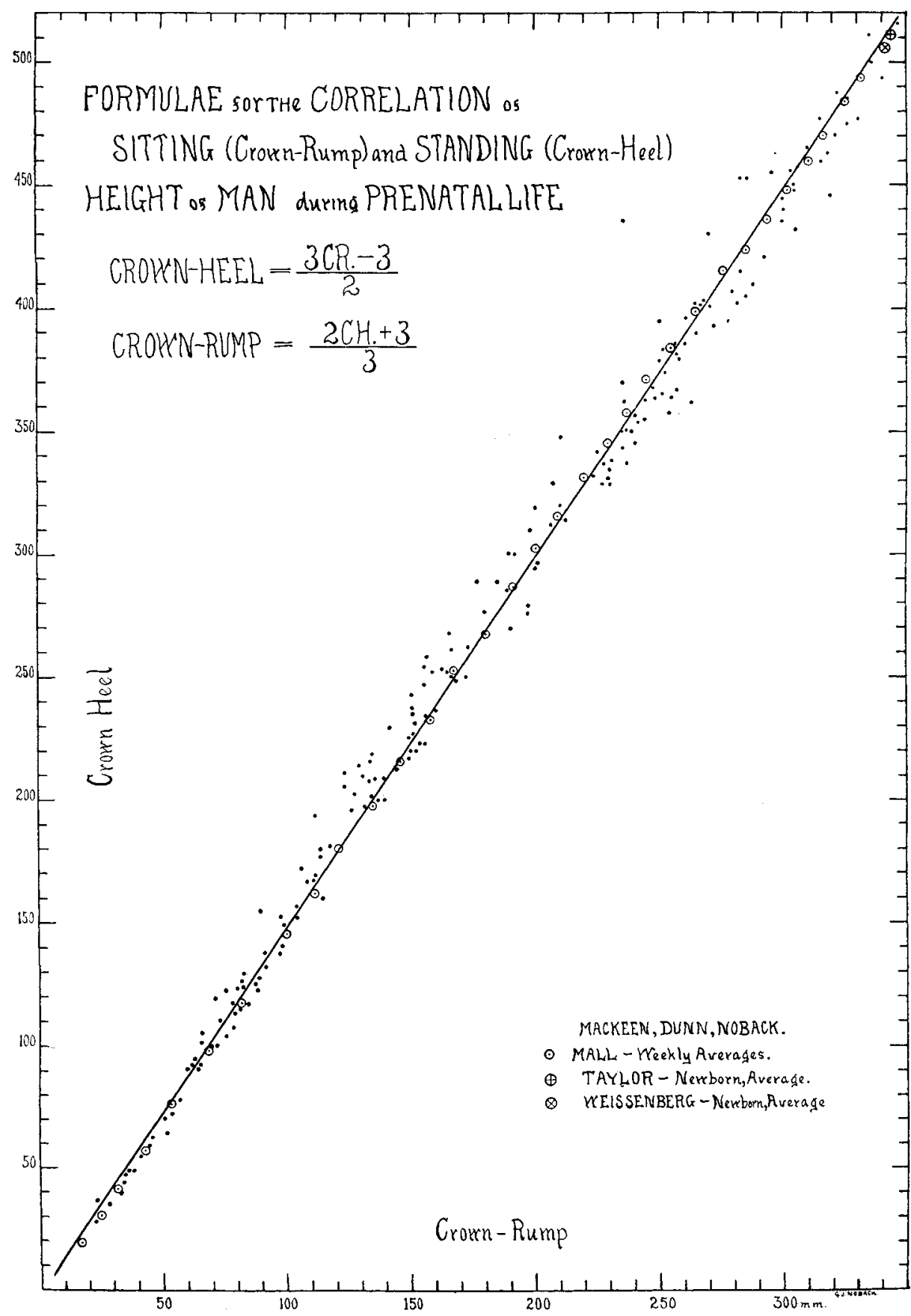




\section{LITERATURE CITED}

MaLl, F. P. 1910 Determination of the age of human embryos and fetuses in Keibel and Mall, Human Embryology, vol. 1, p. 199.

Mrchamuis, PaUr 1906 Alterbestimmung menschlichen Embryonen. Archiv für Gynakologie, Bd. 70.

MeYer, A. W. 1915 Fields, graphs and other data on fetal growth. Contr. to Embryol., no. 4, Carnegie Inst., Wash.

NoвAcK, G. J. 1921 A contribution to the topographic anatomy of the thymus gland, with particular reference to its changes at birth and in the period of the newborn. Amer. Jour. Dis. Child., vol. 22, pp. 120-144.

Scammon, R. E. 1919 Some graphs and tables illustrating the growth of the human stomach. Amer. Jour. Dis. Child., vol. 17, pp. 395-422.

STREETER, G. L. 1920 Weight, sitting height, head size, foot length, and menstrual age of the human embryo. Contr. to Embryol., no. 55, Carnegie Inst. Wash.

TAYLOR, ROOD 1919 The measurements of 250 full-term, new-born infants. Amer. Jour. Dis. Child., vol. 17, pp. 351-362.

Weissenderg, S. 1906 Die Körperproportionen des Neugeborenen. Jahrb. f. Kinderheilkunde, Bd. 64, S. 839. 